\title{
Drinking water quality and handling practices among women in rural households of Oshimili North Local Government Area of Delta State, Nigeria
}

\author{
Elizabeth Omoladun Oloruntoba* and Donald Uzowulu Olannye
}

Department of Environmental Health Sciences, Faculty of Public Health, College of Medicine, University of Ibadan, Ibadan, Nigeria; Email:

li_zzyy@yahoo.com; donalduzowulu@gmail.com

\begin{abstract}
Diarrheal diseases associated with inadequate supply of potable water are the leading causes of mortality among children under five years in developing countries. In Nigeria, women are the water managers in most households. However, there is dearth of information on the effect of women's handling practices on drinking water quality. Therefore, this study was aimed at assessing the drinking water quality and handling practices among women in selected rural households in Oshimili North Local Government Area of Delta State, Nigeria. Paired drinking water samples from available sources and Household Storage Containers (HSC) were assessed for physico-chemical and bacteriological parameters using standard methods. The data obtained were compared with the WHO guideline limits. Water samples with $0,1-10,11-50$ and $>50$ E. coli/100 $\mathrm{mL}$ were graded as $\mathrm{A}, \mathrm{B}, \mathrm{C}$, and $\mathrm{D}$ corresponding to excellent, acceptable, unacceptable, and grossly polluted quality, respectively. Pre-tested semistructured interviewer-administered questionnaire was used to elicit information from the respondents. A 30-point scale was used to assess water handling practices. Handling practice scores greater or equal to mean handling practice score were grouped into good and those less than that were grouped into bad handling practices. Data were analyzed using descriptive statistics and One-way ANOVA at $\alpha=0.05$. The results showed physico-chemical parameters for both sources and households within WHO guideline limits. The mean total coliform counts for all sources and household containers exceeded permissible limits. $E$. coli was not detected in harvested rain water while counts for borehole was 10.2 \pm 2.2 (A) and for stream sources was $44.6 \pm 33.3 \mathrm{EC} / 100 \mathrm{~mL}$ (B); drinking water stored in HSC had $36.8 \pm 32.3$ (A) EC/100 mL, borehole had 62.31 \pm 33.2 (C) and stream had $30.00 \pm 33.2$ (B). Mean handling practice score was $19.4 \pm 6.6$. Majority $(60.0 \%)$ practiced some water handling technique. Drinking water from assessed sources was of poor microbial quality and it significantly deteriorated when stored in household storage containers. Therefore, there is a need to improve the microbial quality of drinking water at sources and household level
\end{abstract}

\footnotetext{
*Corresponding author: li_zzyy@yahoo.com; Telephone number: +234 8028946358
} 
through the supply of simple, acceptable, low-cost treatment methods and hygiene education.

Keywords: Drinking water sources, Handling practices, Illah Storage containers, Water quality

DOI: https://dx.doi.org/10.4314/ejst.v12i3.5

\section{INTRODUCTION}

Good quality drinking water is vital for human physiology and survival. However, several households in many developing countries, especially the African countries, depend solely on drinking water from unsafe sources due to lack of access to safe drinking water (UNICEF, 2012). This may be associated with the rapid population growth and migration of people from rural to urban areas that has put much pressure on existing water resources, and therefore surpassed the capacity of many countries to keep up with the demand. In rural areas, dispersed population pattern and poor road networks could also contribute to lack of access to potable drinking water (Olannye, 2015).

The scarce and inconsistent potable water supply leads to the inevitable practice of households storing it in containers for future use. More often than not, water that is fetched that day is not used completely that same day but stored in plastic, metal, concrete reservoirs or earthenware containers, which influence water quality (Mintz et al., 1995; Jensen et al., 2002; Oloruntoba and Sridhar, 2007; Levy et al., 2008; Oloruntoba et al, 2016; Olannye, 2015; Kaoje et al., 2019). The consumption of unsafe water has been linked to the prevalence of diseases such as diarrhoea, cholera, infective hepatitis and schistosomiasis (Gyoh, 2011; Oloruntoba et al., 2014; Miner et al., 2015; Gwimbi et al. 2019; Kaoje et al., 2019). However, diarrhea has recently been confirmed by Gwimbi et al. (2019) as the leading cause of illness in majority of rural households in Mohale Basin, Lesotho, where unsafe water consumption was linked to the prevalence of this disease. The World Health Organization (WHO) estimated about 2.2 million deaths from diarrhea cases annually as a result of unsafe water consumption (WHO, 2014).

Several studies have revealed that the rural communities of Nigeria are still faced with the problem of low access to safe drinking water (Ibiene et al., 2012; NPC, 2014; Olukanni et al., 2014; Olannye et al., 2017; Adeniran, 2018; Kaoje et al., 2019). Diarrhoeal diseases linked to unsafe water consumption have been confirmed in previous studies as the major 
health problem that still persists in Nigeria rural communities (Oloruntoba et al., 2014; Miner et al., 2015; Kaoje et al., 2019). Addressing issues relating to household drinking water quality can drastically reduce health problems associated with water consumption from unsafe sources. This study was, therefore, undertaken to assess the water quality and handling practices of women in rural households of Oshimili North Local Government Area of Delta State, Nigeria.

\section{MATERIALS AND METHODS}

\section{Study area}

Delta State is one of the oil-producing states in Nigeria located in the south-south geo-political zone of the Niger Delta region. The State covers an area of $17,698 \mathrm{~km}^{2}$ within $5^{\circ} 30^{\prime} \mathrm{N}$ and $6^{\circ} 00^{\prime} \mathrm{E}$ and comprises 25 local government areas. Delta State is made up of three senatorial districts, namely Delta North, Delta South and Delta Central. The study area is Oshimili North Local Government Area (LGA), one of the LGAs in Delta North Senatorial district of Delta State, Nigeria. It has a total population of about 157, 819 (77,353 males and 80,466 females) according to the projected 2015 estimates (Delta State Population Census, 2011).The LGA has eight wards, of which the study area (Ward 3 ) is the largest in terms of geographical area, number of rural households and water sources. In Ward 3 (Illah Community), the rural households share 8 boreholes, 4 streams and 2 rain water harvesting wells. The inhabitants of the area are normally farmers, fishers and traders.

\section{Study design}

A community-based descriptive cross-sectional design involving survey and laboratory analyses of drinking water from sources to households was adopted for the study.

\section{Study population}

Women within the age group of 18-65 in Illah community constituted the study population.

\section{Sample size}

Considering the low number of water sources in the selected study area, total sampling was employed. Eighty rural households in the community that utilize these water sources for drinking were purposively selected to participate in the study. 


\section{Sampling procedure}

Multi-stage sampling technique was used for sample selection. Delta North senatorial district was purposively selected based on the large number of LGAs. Oshimili North LGA was picked by balloting. Illah community in ward three was purposively selected from eight wards that make up the LGA based on the large geographical land area and the number of rural households and sources. Illah community was stratified into three major strata using the distinctive features on the map (three major roads). In each stratum, only one of the three neighborhoods were picked by balloting. The households in each stratum were then numbered to obtain the total number of 640 households in the community. Out of this number, only 80 households utilizing the identified water sources as at the time of the study consented to participate. Purposive sampling was used to select a female within the age group of 18-65 years from each of the identified rural households. Drinking water samples were collected from the sources used by selected households and from their storage containers.

\section{Data collection methods and instrument}

\section{Survey}

A semi-structured self-administered questionnaire was used to elicit information from each woman in selected households on the sociodemographic characteristics of the respondents, current household drinking water sources and water handling practices during collection, storage and use.

\section{Sanitary inspection}

Sanitary inspection forms were used to capture the sanitary conditions of commonly used sources and household storage containers in the community. The forms comprised of 10 questions designed for a "Yes" (correct answer) or "No" answer.

\section{Sample collection for determination of physico-chemical parameters}

Plastic kegs of two liters capacity and plastic bottles of 60 milliliters capacity were washed with detergents and rinsed with distilled water then dried. All the containers were closed afterwards until the point of sample collection. After sample collection from the sources and household storage containers, the levels of physico-chemical parameters: $\mathrm{pH}$, nitrate, lead, iron, and zinc were determined using standard methods 
developed by United States Environmental Protection Agency (USEPA) (USEPA, 1996) and American Public Health Association (APHA) (APHA, 1998).

\section{Sample collection for microbial analysis}

Glass sample bottles were properly washed, rinsed with distilled water, dried and sterilized in an oven at $170{ }^{\circ} \mathrm{C}$ for one hour. All the containers were closed until the point of sample collection.

\section{Borehole water}

Before collecting water samples from the borehole, the faucet was swabbed with cotton wool soaked with $70 \%$ alcohol. Then the tap was turned on for five minutes to clear the water lines. The faucet was then sterilized with flame from a spirit lamp for a minute. The water was allowed to run afterwards for five minutes to clear the pipe lines. Sample bottles were carefully opened and the outside of the cap was held in order not to contaminate the container or cap. The container was filled and the top replaced (after flaming), stored in a cool box with ice packs and transported to the laboratory. Analysis was done within six hours of sample collection.

\section{Stream water}

Before collecting water samples from the stream, the sterile sample bottle cover was removed aseptically, and the mouth of the bottle was faced upwards. The neck was plunged downwards about $30 \mathrm{~cm}$ below the water surface, and then the neck was tilted slightly upwards to let it fill completely before carefully replacing the cap and cover. The sample bottles were covered, stored in a cool box with ice packs and transported to the laboratory. Analyses were done within six hours. This procedure was the same procedure used for drawing water samples from the shallow well since water in it was of little depth.

\section{Water from household storage containers}

Water samples were collected from household storage containers under aseptic conditions. The samples were immediately stored in ice packs and transported to the laboratory for analyses within 6 hours.

\section{Determination of bacteriological quality}

Samples were appropriately diluted with sterile diluent up to $1: 100 / 1000$ and analysed for total coliforms (TC) and Escherichia coli (EC) using standard methods by APHA (1998). Lactose fermentation test was carried out to detect and enumerate the number of TC using MacConkey broth at $37{ }^{\circ} \mathrm{C}$ for $18-24 \mathrm{~h}$. Thereafter, positive bottles showing gas 
formation (in small $30 \mathrm{~mm}$ inverted Durham tubes) and colour change (from purple to yellow) were sub-cultured into sterile brilliant green bile broth and incubated at $44{ }^{\circ} \mathrm{C}$ for $18-24 \mathrm{~h}$. Gas formation showed presence of Escherichia coli. Results were estimated statistically and expressed as $\mathrm{TC}$ or $\mathrm{EC}$ count $/ 100 \mathrm{ml}$.

\section{Data management and statistical analysis}

Data was entered and analyzed using statistical package for the social sciences (SPSS) version 20. Data from the survey were analysed using descriptive statistics. The water handling practices was on a scale of 30 points comprising of 6 water handling practice questions whose scoring was based on positive option for correct response, and zero for incorrect response. All correct responses in each questionnaire were summed up to a total score. Then the scores were pooled together into SPSS for analysis using descriptive statistics (mean, standard deviation, maximum and minimum) to get the mean handling practice score. Handling practice score $\geq$ mean score was grouped into good handling practice and handling practice score $<$ mean score was grouped into bad handling practice. The sanitary inspection form was designed on a scale of ten points. Aggregate scores ranging from $0-2$ (low risk), $3-5$ (medium risk), $6-8$ (high risk) and $9-10$ (very high risk). The results from sanitary inspection were analysed using descriptive statistics to get the mean, standard deviation, maximum value, minimum value and percentages. Levels of water quality parameters at collection points and household storage containers were summarized using descriptive statistics (mean, standard deviation, maximum and minimum values). ANOVA was used to determine the statistical difference in the mean levels of water quality parameters among the sources and also within the households. Chi-square was used to test the association between qualitative variables (storage conditions) and water quality. Using the classification of Cheesbrough (1984), water sample with 0 faecal coliform count per $100 \mathrm{~mL}$ was considered to be of excellent quality (grade A), 1-10 colonies per $100 \mathrm{~mL}$ was acceptable (grade B), 11-50 colonies per $100 \mathrm{~mL}$ was unacceptable (grade C), and counts of more than 50 colonies per $100 \mathrm{~mL}$ was considered as grossly polluted (grade D). All analyses were carried out at $5 \%$ level of significance.

\section{Ethical approval}

This study is a part of a larger one that looked into household characteristics and use of indigenous treatment methods for treating household drinking water in Illah community of Delta State, Nigeria. 
Ethical approval for this study was obtained from Delta State Ministry of Health, while verbal approval was obtained from the participants.

\section{RESULTS}

\section{Socio-demographic characteristics of the participants}

The results of the survey showed that the overall mean age was $34.8 \pm 12.5$ years of which $31(38.7 \%)$ were below 30 years, $40(50.0 \%)$ were within $30-50$ years and $9(11.3 \%)$ were above 50 years of age. Majority of the respondents were Christians and Igbo. From the socioeconomic status of respondents, less than half 29 (36.2\%) engaged in trading while $8(10.0 \%)$ were full time housewives. The highest level of education attained by all respondents in the study revealed that half 40 $(50.0 \%)$ of the respondents had up to primary school education; 26 $(32.5 \%)$ had up to secondary school education and $14(17.5 \%)$ had no formal education (Table 1).

\section{Water supply}

The sources of drinking water for the 80 respondents were borehole, stream, and harvested rainwater recharged well. Majority $64(80.0 \%)$ of the respondents used boreholes as their source of drinking water, 13 (16.2\%) used streams and $3(3.8 \%)$ used harvested rainwater recharged wells (Figure 1).

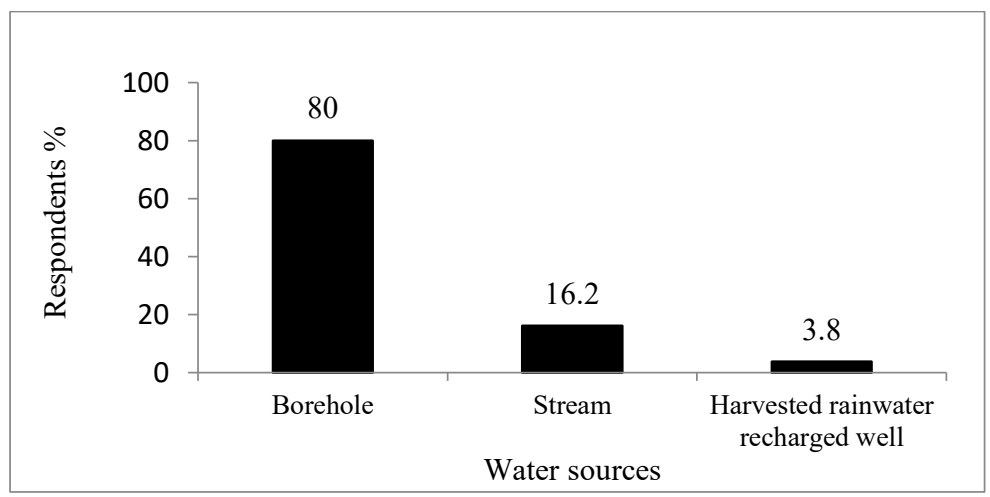

Figure 1. Respondents' drinking water sources in Illah Community.

\section{Water handling practices}

Results of the survey showed that during transportation majority of the respondents $76(95.0 \%)$ covered their drinking water containers after 
collecting water from the sources. Also, majority of the respondents 76 $(95.0 \%)$ claimed not to use the bucket for fetching drinking water for other domestic purposes.

Table 1. Socio-demographic characteristics.

\begin{tabular}{llcc}
\hline Socio-demographic factors & Number & $\mathbf{\%}$ \\
\hline Sex & All females & 80 & 100 \\
Age & $<30$ & 31 & 38.7 \\
& $30-50$ & 40 & 50.0 \\
Ethnicity & $>50$ & 9 & 11.3 \\
& Ibo & 69 & 86.2 \\
Religion & Non - ibo & 11 & 13.8 \\
& Christian & 68 & 85.0 \\
Occupation & Islam & 3 & 3.8 \\
& Traditional & 9 & 11.2 \\
& Trade & 29 & 36.2 \\
& Artisan & 11 & 13.8 \\
& Farming & 17 & 21.2 \\
Level of Education & Student & 15 & 18.8 \\
& House wife & 8 & 10.0 \\
& No formal education & 14 & 17.5 \\
& Primary school & 40 & 50.0 \\
& Secondary school & 26 & 32.5 \\
\hline
\end{tabular}

The results of the survey also showed that more than half of the respondents in the households $(58.8 \%)$ stored their drinking water in wide-mouthed containers (plastic containers like buckets and clay pots) and drew water from them to drink by dipping cups while $41.2 \%$ stored drinking water in narrow-mouthed containers (plastic kegs/ jerricans) and drew water by pouring (Table 2 ). The mean water handling practice was $19.4 \pm 6.6$ (range: $5-30$ ). Forty-eight (or $60 \%$ ) of the respondents had bad water handling practices.

\section{Sanitary condition of drinking water sources and household storage containers of the respondents}

Observation using the sanitary inspection forms showed that the mean risk score for the water sources $(2.6 \pm 1.5)$ was slightly higher than that of the household storage containers $(2.2+1.4)$. The risk scores varied between 0 and 4 for the water sources; and $0-6$ for the household storage containers. Figure 2 shows the level of risk associated with the water sources and household storage containers. 


\section{Physico-chemical quality of drinking water from sources and households}

The mean values for physico-chemical parameters of drinking water from sources and households are presented in Table 3. The mean values obtained for $\mathrm{pH}$, nitrate, lead, zinc and iron were within the WHO guideline limits of $6.5,500 \mathrm{mg} / \mathrm{L}, 50 \mathrm{mg} / \mathrm{L}, 0.01 \mathrm{mg} / \mathrm{L}, 3 \mathrm{mg} / \mathrm{L}$ and 0.3 $\mathrm{mg} / \mathrm{L}$, respectively. Water sources significantly varied in all parameters analysed except nitrates. However, for the household storage containers, only iron showed a significant difference (Table 4).

Table 2. Water handling practices.

\begin{tabular}{lll}
\hline Variables & Number & $\%$ \\
\hline
\end{tabular}

Use of bucket for fetching drinking water for other domestic purpose

$\begin{array}{lrr}\text { Yes } & 4 & 5.0 \\ \text { No } & 76 & 95.0\end{array}$

Covering drinking water during transportation

$\begin{array}{lrr}\text { Yes } & 76 & 95.0 \\ \text { No } & 4 & 5.0\end{array}$

Types of storage container

$\begin{array}{lll}\text { Jerrican (Narrow-mouthed) } & 33 & 41.2\end{array}$

Plastic Buckets (Open-mouthed) $\quad 38 \quad 47.5$

$\begin{array}{lll}\text { Clay Pots (Open-mouthed) } & 9 & 11.3\end{array}$

Frequency of cleaning storage container

Daily $\quad \begin{array}{ll}14 & 17.5\end{array}$

Once a Weekly $\quad 41 \quad 51.3$

$\begin{array}{lll}\text { When dirty } & 25 & 31.2\end{array}$

Special container for water collection from storage container

$\begin{array}{lll}\text { Yes } & 78 \quad 97.5\end{array}$

$\begin{array}{lll}\text { No } & 2 & 2.5\end{array}$

Mode of collecting drinking water from storage containers

$\begin{array}{lll}\text { By pouring } & 33 & 41.2 \\ \text { By dipping } & 47 & 58.8\end{array}$

Keeping of your drinking water

$\begin{array}{lll}\text { In the room } & 57 & 71.2\end{array}$

$\begin{array}{lll}\text { Outside room } & 4 & 5.0\end{array}$

\begin{tabular}{lll} 
In the Kitchen & 17 & 21.3 \\
\hline
\end{tabular}

\begin{tabular}{lll} 
Outside Kitchen & 2 & 2.5 \\
\hline
\end{tabular}

\section{Bacteriological quality of drinking water from sources and households \\ The mean values for bacteriological quality of drinking water from sources and households are presented in Table 5. The mean values obtained for total coliforms and E. coli counts exceeded the WHO}


guideline limits of $10 \mathrm{TC} / 100 \mathrm{~mL}$ and $0 \mathrm{EC} / 100 \mathrm{~mL}$ except for harvested rain in the well, which had no $E$. coli count.

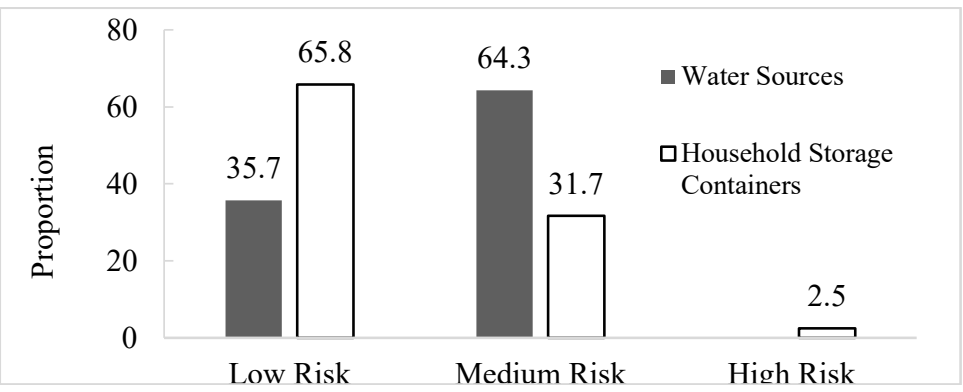

Figure 2. Sanitary conditions of water sources and household storage containers.

Table 4. Variations in physico-chemical quality of drinking water from source and household.

\begin{tabular}{|lcc|c|c|c|}
\hline \multirow{2}{*}{ Parameter } & \multicolumn{2}{c|}{ Sources } & & \multicolumn{2}{c}{ Households } \\
\cline { 2 - 3 } \cline { 5 - 5 } & $\boldsymbol{F}$ value & $\boldsymbol{P}$-value & & $\boldsymbol{F}$ value & $\boldsymbol{P}$-value \\
\hline pH & 24.028 & 0.000 & & 1.554 & 0.218 \\
Nitrate & 1.030 & 0.362 & & 1.203 & 0.306 \\
\hline Lead & 3.833 & 0.026 & & 0.654 & 0.523 \\
\hline Zinc & 3.236 & 0.045 & & 0.327 & 0.722 \\
Iron & 5.744 & 0.005 & & 3.904 & 0.024 \\
\hline
\end{tabular}

Table 5. Bacteriological quality of drinking water.

\begin{tabular}{llllllll}
\hline Parameter & \multicolumn{2}{c}{ Borehole $(\mathbf{n}=\mathbf{6 4})$} & \multicolumn{2}{c}{ Stream $(\mathbf{n}=\mathbf{1 3})$} & \multicolumn{2}{c}{ Well $(\mathbf{n}=\mathbf{3})$} & WHO \\
\cline { 2 - 5 } & Source & Household & Source & Household & Source & Household & \\
STD
\end{tabular}


Table 3. Physico-chemical quality of drinking water.

\begin{tabular}{|c|c|c|c|c|c|c|c|}
\hline \multirow[t]{2}{*}{ Parameters } & \multicolumn{2}{|c|}{ Borehole $(n=64)$} & \multicolumn{2}{|c|}{ Stream $(n=13)$} & \multicolumn{2}{|c|}{ Well $(n=3)$} & \multirow{2}{*}{$\begin{array}{l}\text { WHO } \\
\text { Limits }\end{array}$} \\
\hline & Source & Household & Source & Household & Source & Household & \\
\hline & & & pH & & & & \\
\hline $\operatorname{Mean} \pm \mathrm{SD}$ & $6.63 \pm 0.5$ & $7.13 \pm 0.5$ & $7.31 \pm 0.4$ & $7.34 \pm 0.6$ & $7.21 \pm 0.02$ & $7.64 \pm 0.5$ & $6.5-$ \\
\hline Minimum & 6.04 & 6.10 & 6.80 & 6.30 & 7.20 & 7.10 & 8.5 \\
\hline Maximum & 7.47 & 7.70 & 7.67 & 8.20 & 7.24 & 8.02 & \\
\hline & & & Nitrate $(\mathrm{mg} / \mathrm{L})$ & & & & \\
\hline Mean \pm SD & $14.30 \pm 5.1$ & $16.21 \pm 7.1$ & $15.87 \pm 1.3$ & $22.37 \pm 4.6$ & $12.52 \pm 1.5$ & $17.28 \pm 6.3$ & 50 \\
\hline Minimum & 5.10 & 4.87 & 14.40 & 17.06 & 10.19 & 5.54 & \\
\hline Maximum & 23.92 & 42.53 & $\begin{array}{c}16.61 \\
\text { Lead (mg/L) }\end{array}$ & 25.47 & 16.39 & 26.14 & \\
\hline $\mathrm{Mean} \pm \mathrm{SD}$ & $0.0069 \pm 0.0006$ & \pm 0.002 & $0.0070 \pm 0.0004$ & \pm 0.002 & $0.0060 \pm 0.0005$ & $0.0045 \pm 0.0008$ & 0.01 \\
\hline Minimum & 0.0061 & 0.0016 & 0.0067 & 0.0025 & 0.0055 & 0.0036 & \\
\hline Maximum & 0.0076 & 0.0083 & $\begin{array}{c}0.0076 \\
\text { Zinc (mg/L) }\end{array}$ & 0.0077 & 0.0063 & 0.0050 & \\
\hline $\operatorname{Mean} \pm \mathrm{SD}$ & $1.25 \pm 0.6$ & $1.36 \pm 0.7$ & $1.60 \pm 0.1$ & $1.53 \pm 0.4$ & $0.98 \pm 0.02$ & $1.42 \pm 0.5$ & 3 \\
\hline Minimum & 0.53 & 0.10 & 1.54 & 0.93 & 0.956 & 1.12 & \\
\hline Maximum & 2.61 & 3.07 & $\begin{array}{c}2.01 \\
\text { Iron }(\mathbf{m g} / \mathbf{L})\end{array}$ & 2.41 & 0.984 & 1.99 & \\
\hline Mean \pm SD & $0.18 \pm 0.1$ & $0.14 \pm 0.09$ & $0.13 \pm 0.05$ & $0.16 \pm 0.05$ & $0.30 \pm 0.2$ & $0.29 \pm 0.1$ & 0.3 \\
\hline Minimum & 0.06 & 0.01 & 0.09 & 0.06 & 0.10 & 0.10 & \\
\hline Maximum & 0.50 & 0.40 & 0.26 & 0.20 & 0.50 & 0.40 & \\
\hline
\end{tabular}


Thus, all water samples from harvested rainwater recharged wells had excellent quality (Figure 3 ). When all sources were pulled together, only $42.9 \%$ had excellent quality, while $28.6 \%$ were completely polluted (Figure 4). With regards to the household storage containers only $17.5 \%$ were of excellent quality (Figure 5). Table 6 shows the variations in bacteriological quality of drinking water from source and household.

Table 6. Variations in bacteriological quality of drinking water from source and household.

\begin{tabular}{ccccc}
\hline Parameter & \multicolumn{2}{c}{ Sources } & \multicolumn{2}{c}{ Households } \\
\cline { 2 - 5 } & $\begin{array}{c}\text { F- } \\
\text { value }\end{array}$ & $\begin{array}{c}\text { P- } \\
\text { value }\end{array}$ & $\begin{array}{c}\text { F- } \\
\text { value }\end{array}$ & $\begin{array}{c}\text { P-value } \\
\text { Decision }\end{array}$ \\
\hline TCC & 7.007 & 0.002 & 1.139 & 0.325 \\
EC & 15.211 & 0.000 & 3.478 & 0.036 \\
\hline
\end{tabular}

\section{Association between storage condition and water quality}

Collection of water by pouring and cleaning of storage containers daily showed a significant reduction in the concentration of faecal coliform count at the point of storage. Furthermore, water stored in jerricans were found to have significantly better bacteriological quality than water stored in plastic buckets and clay pots (Table 7; Figures 6,7 and 8).

Table 7. Association between storage condition and water quality.

\begin{tabular}{|c|c|c|c|c|}
\hline \multirow[t]{2}{*}{ Variables } & \multicolumn{2}{|c|}{ Household Water } & \multirow{2}{*}{$\begin{array}{l}\text { Chi } \\
\text { square } \\
x^{2}\end{array}$} & \multirow{2}{*}{$\begin{array}{l}P \text { - } \\
\text { value }\end{array}$} \\
\hline & $\begin{array}{l}\leq 10 \text { faecal } \\
\text { coliform } \\
\text { counts/ } \\
100 \mathrm{~mL}\end{array}$ & $\begin{array}{l}>10 \text { faecal } \\
\text { coliform } \\
\text { counts } \\
/ 100 \mathrm{~mL}\end{array}$ & & \\
\hline \multicolumn{5}{|c|}{ Storage containers } \\
\hline Jerican & 14 & 19 & 24.17 & $0.00 *$ \\
\hline Plastic Buckets & 0 & 38 & & \\
\hline Clay Pots & 0 & 9 & & \\
\hline \multicolumn{5}{|c|}{ Frequency of Cleaning Storage Containers } \\
\hline Daily & 14 & 0 & 80.00 & $0.00 *$ \\
\hline Once a week & 0 & 41 & & \\
\hline When Dirty & 0 & 25 & & \\
\hline \multicolumn{5}{|c|}{ Mode of water collection from storage container } \\
\hline Pouring & 14 & 19 & 24.17 & $0.00 *$ \\
\hline Dipping & 0 & 47 & & \\
\hline
\end{tabular}




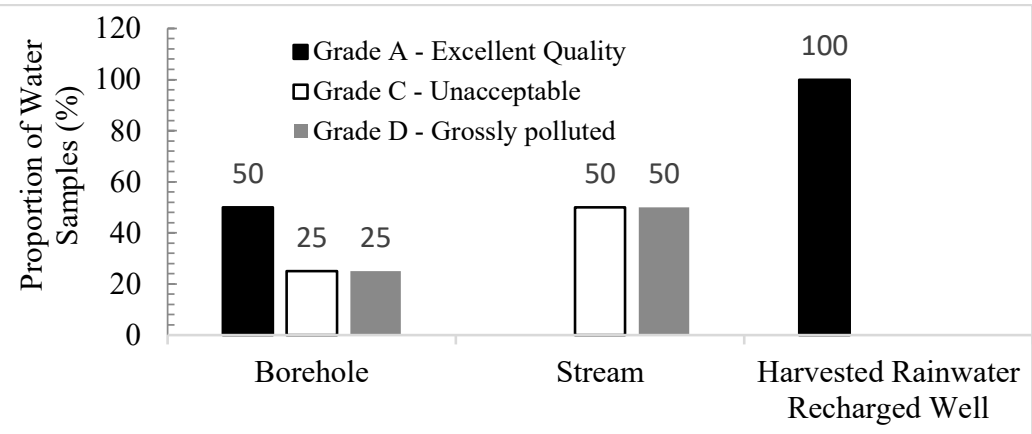

Figure 3. Grade levels of water samples from different sources.

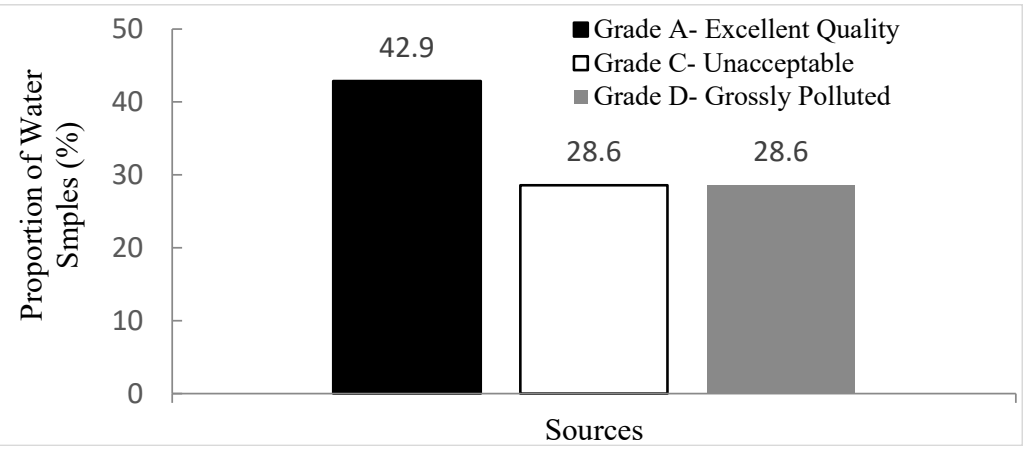

Figure 4. Grade levels of water samples from all sources.

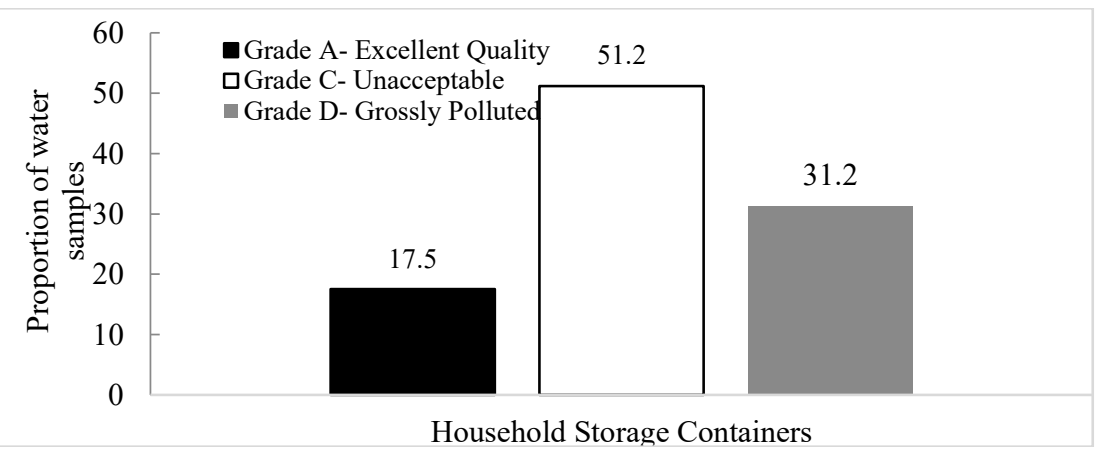

Figure 5. Grade levels of water samples from household storage containers. 


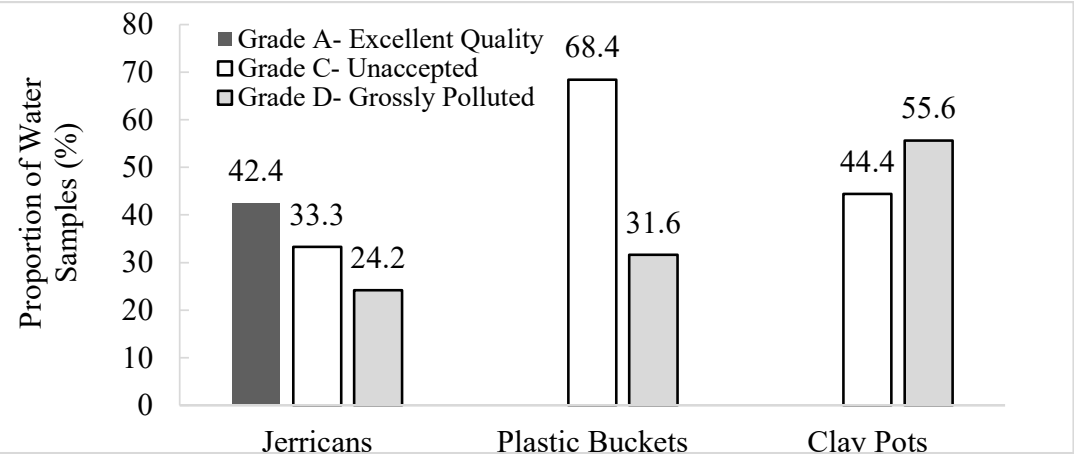

Figure 6. Grade levels of water samples from different storage containers.

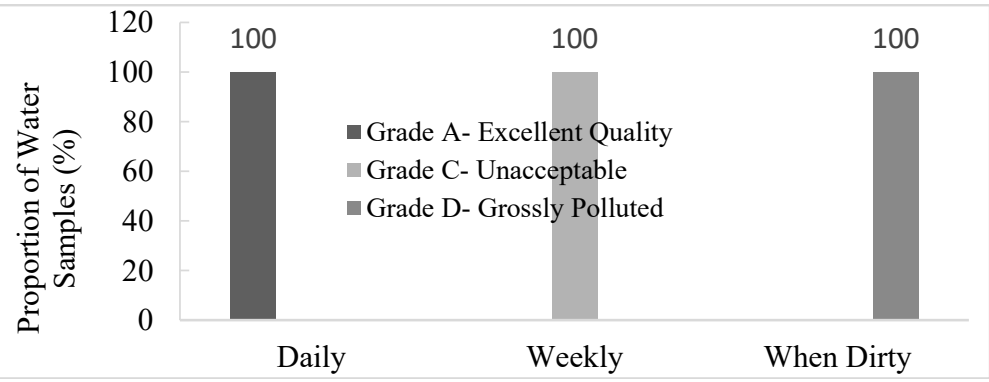

Figure 7. Grade levels of water samples by frequency of cleaning storage containers.

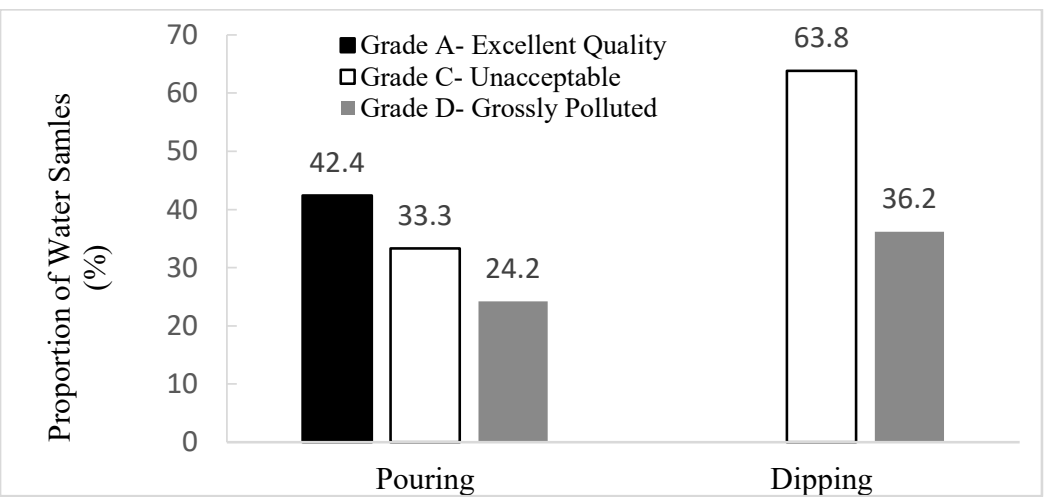

Figure 8. Grade levels of water samples by mode of collection from storage container. 


\section{DISCUSSION}

The levels of $\mathrm{pH}$, nitrate, lead, iron and zinc in the household drinking water sources were in compliance with the WHO guideline limit of drinking water. It was partly in agreement with the report on comparative assessment of the quality of harvested rainwater, ground water and surface water in one of the rural communities in Delta State, which showed that the levels of $\mathrm{pH}$ and zinc in harvested rainwater, ground water and surface water were within the WHO permissible standard. In contrast, the report revealed that the iron concentrations which were higher in the surface water showed unacceptable levels when compared to well water and harvested rain water that showed acceptable levels (Ushurhe and Origho, 2013). Majority of the water samples collected from the household water supplies in this study were positive for total and faecal coliform counts. This finding does not conform to the WHO guidelines (WHO, 1996) which required that water intended for drinking should be free of pathogens and bacterial indicative of faecal contamination. However, the results corroborate other works (Ibiene et al., 2012; Olukanni et al., 2014; Olannye et al., 2017; Adeniran, 2018; Kaoje et al., 2018; Gwimbi et al., 2019), who reported total and faecal coliform counts far exceeding the WHO guideline limit of drinking water in all the water sources present in one of the rural communities in Delta State.

The study also revealed that the stream water had the highest faecal coliform counts. This corroborates reports by Albert et al. (2010), which assessed rural drinking water quality in Kenya and reported that the stand pipe (tap) water and harvested rain had significantly less E. coli than surface water (earth pan and rivers). The type of storage containers in this study significantly influenced the water quality consumed by the household. Similar results were reported before (Jensen et al., 2002; Oloruntoba and Sridhar, 2007; Levy et al., 2008; Oloruntoba et al., 2016; Olannye, 2015; Kaoje et al., 2018). Storage containers and level of microbial contamination have significant association (Jensen et al., 2002; Oloruntoba et al., 2014)). The influence of water storage on microbial levels was also evident in the interventional study where Escherichia coli counts in stored household waters were $<1 / 100 \mathrm{~mL}$ in most intervention households (household where water chlorination and storage in a special container was practiced) but readily detectable at high levels in control households (Sobsey et al., 2003). 
Furthermore, the use for water storage of plastic buckets and clay pots with wide mouth in this study led to dipping of containers/cups to draw water for use. This method of water collection significantly influenced the water quality via using contaminated container used to draw water from the storage container. Also, the possibility of dipping contaminated hands into the containers during the process of collection cannot be ruled out (Sobsey et al., 2003; Tambekar and Mahore, 2005). It has also been confirmed in previous studies that bacteriological quality of drinking water generally deteriorated in household storage containers (Jensen et al., 2002; Oloruntoba and Sridhar, 2007; Levy et al., 2008; Olannye, 2015; Oloruntoba et al., 2016).

\section{CONCLUSION AND RECOMMENDATION}

Bacteriological quality (total coliform and E. coli counts) of drinking water sources (boreholes, stream and wells) and at the household levels (only E. coli count) significantly varied. Also, significant relationship exists between bacteriological quality and handling practices. This implies that since the proportion of contaminated water samples and bacteria counts were high at the household level; there is also high risk of contracting water-borne diseases through the consumption of these sources of water. Therefore, it should be recommended that household drinking water quality could be improved through hygiene education with the propagation of the use of simple, acceptable, low-cost treatment methods (such as solar disinfection, household sand filters and boiling) and use of narrow mouthed containers like jerricans and bottles for storage to reduce dipping of cups, bowls and hands to improve the microbial quality of household stored drinking water.

\section{CONFLICT OF INTEREST}

The authors have no competing interests to declare.

\section{ACKNOWLEDGEMENTS}

The authors are grateful to the Obi (King) and residents of Illah Community who contributed to the successful completion of this study. The technical support from Delta State University Postgraduate Laboratory, Asaba, Delta State, Nigeria, is also gratefully acknowledged. 


\section{REFERENCES}

Adeniran, A. (2018). Assessment of water quality in slum area in Ibadan. Hydrology: Current Research 9(1): 1 - 20

Albert, J., Luoto, J and Levine, D. (2010). End- user preferences for and performance of competing POU water treatment technologies among the rural poor of Kenya. Environmental Science and Technology 44(12): 4426-4432.

APHA (American Public Health Association). (1998). American Water Works Association and Water Environment Federation Standard methods for the Examination of Water and Waste water. American Public Health Association, Washington, D.C.

Cheesbrough, M. (1984). Medical laboratory manual for tropical countries, Vol. II, Butter worth Heinemann Ltd. Oxford.

Delta State Population Census (2011). Delta state population by sex and LGA Projected from 2006 National Census Figures to 2015. Fact Sheet, Delta State, Nigeria. https://www.deltastate.gov.ng, (accessed November 19, 2019)

Gwimbi, P., Maeti, G and Motena, R. (2019). Bacteriological contamination of drinking water sources in rural villages of Mohale Basin, Lesotho: Exposures through neighborhood sanitation and hygiene practices. Environmental Health and Preventive Medicine 24 (33): 1 - 7

Gyoh, S.K. (2011). Cholera epidemics in Nigeria: An indictment of the shameful neglect of government. African Health 33(1): 5

Ibiene, A.A., Agbeyi, E.V and Okonko, I.O. (2012). Bacteriological assessment of drinking water sources in Opuraja Community of Delta State, Nigeria. Nature and Science 10(1): 36-41

Jensen, P.K., Ensink, J.H and Jayasinghe, G. (2002). Domestic transmission routes of pathogens: the problem of in-house contamination of drinking water during storage in developing countries. Journal of Tropical Medicine and International Health 7(7): 604-609.

Kaoje, U., Yahaya, M., Raji, O., Hadiza, M and Adenekan, S. (2018). Drinking water quality, sanitation and hygiene practices in a rural community of Sokoto State, Nigeria. International Journal of Medical Science and Public Health 8(1): $78-85$

Levy. K., Nelson, K.L., Hubbard, A., Joseph, N.S and Eisenberg, J.N.S (2008). Following the water: A controlled study of drinking water storage in Northern Coastal Ecuador. Environmental Health Perspectives 116(11): 1533-1540.

Miner, C.A., Dakhin, A.P., Zoakah, A.L., Afolaranmi, T.O and Envuladu, E.A. (2015). Household drinking water; knowledge and practice of purification in Lamingo Community, Plateau State, Nigeria. E3 Journal of Environmental Research and Management 6(3): 0230 - 0236

Mintz, E.D., Reiff, F.M and Tauxe, R.V. (1995). Safe water treatment and storage in the home: A practical new strategy to prevent waterborne disease. Journal of the American Medical Association 273: 948-953.

NPC (National Population Commission), Nigeria (2014). Nigeria Demographic and Health Survey 2013. Fact sheet, Nigeria. https://dhsprogram.com/pubs/pdf/FR293/FR293.pdf.

Olannye, D.U (2015). Effect of smoke treatment with Xylopia aethiopica and Tetrapleura tetraptera on the quality of drinking water in Illah Community, Delta State. MPH Dissertation, University of Ibadan, Nigeria. 
Olannye, D.U., Oloruntoba, E.O and Ana, G.R. (2017). Effectiveness of indigenous household water treatment on the bacteriological quality of drinking water in Illah Community, Oshimili North LGA, Delta State, Nigeria. African Journal of Environmental Health Sciences 4(1): 41 - 50

Oloruntoba, E.O., Folarin, B.T and Ayede, I.A. (2014). Hygiene and sanitation risk factors of diarrhoeal disease among under-five children in Ibadan, Nigeria. African Health Sciences 14(4): 1001 - 1011

Oloruntoba E.O and Sridhar M.K. (2007). Bacteriological quality of drinking water from source to household in Nigeria. African Journal of Medical Science 36(2): $169-175$.

Olukanni, O.D., Ebuetse, A.M and Anake, U.W. (2014). Drinking water quality and sanitation issues: A survey of a semi-urban setting in Nigeria. International Journal of Research in Engineering and Science 2(11): 58 - 65

Oloruntoba, E.O., Babalola, T.F., Morakinyo, O.M and Adejumo, M. (2016). Effects of improved storage containers on the bacteriological quality of household drinking water in low-income urban communities in Ibadan, Nigeria. Water Science and Technology: Water Supply 16(2): 378 -387. doi: 10.2166/ws.2015.147 https://iwaponline.com/ws/article-abstract/16/2/378/3134

Sobsey, M., Handzel T and Venczel, L. (2003). Chlorination and safe storage of household drinking water in developing countries to reduce waterborne disease. Water Science and Technology 47(3): 221-228

Tambekar, D. and Mahore, A. (2005). Studies on personal and domestic hygiene practices on storage and handling of drinking water in houses. Pollution Research 24: 337-381

UNICEF (2012). Water, sanitation and hygiene. http://www.unicef.org/wash/index_43106.html (accessed 10 October 2016).

USEPA (United States Environmental Protection Agency). (1996). Reference manual for analytical methods for water, soil, and sludge, method 3050B, Office of Research and Development, Washington DC, USA.

Ushurhe, O and Origho, T. (2013). A comparative assessment of the quality of harvested rainwater, underground water and surface water for Domestic Purposes in Ughelli, Southern Nigeria. Journal of Environment and Earth Science 3(12): 9-14

WHO (World Health Organization). (1996). Guidelines for drinking-water quality (vol. 2): Health Criteria and other supporting information, Geneva, Switzerland. pp 940 - 949.

WHO (World Health Organization). (2014). Water-related diseases. Water sanitation and health. http://www.who.int/water_sanitation_health/diseases/diarrhoea/en/. (Accessed 10 November 2018). 